\section{Years of Publications by the Microscopy Society of America}

To commemorate the 25th anniversary of the then-named Electron Microscopy Society of America, the Society published its first hardbound volume of proceedings papers in advance of the annual meeting in Chicago, August 29, 1967. Program Chair Claude Arceneaux edited the 375-page book that contained 186 extended abstracts in the familiar two-page format, the same style in use today. This respected annual proceedings series has continued in various formats under the leadership of Editors GW Bailey, S McKernan, J Shields, and G Celio.

In November 1971, the Society launched the EMSA Bulletin to consolidate various mailings and to encourage letters to the editor discussing problems and criticisms about electron microscopy. Editor RK Hart, followed by EL Thurston, LC Sawyer, R Anderson, and JM Harb, progressively improved this publication, later titled MSA Bulletin, into a highly successful communications vehicle. More recently, Society news and meeting information has been transferred to the email newsletter MSA Update and the MSA website (microscopy.org), which also contains the President's Blog.

When I was MSA president in 1991, we decided the Society should have a peer-reviewed journal. Joe Harb helped me fashion a "demo journal" that we published as a special issue of the MSA Bulletin in March 1992. The success of that project led us to seek a publisher, and publication of what became Microscopy and Microanalysis began in 1995. Over the years our Editors, led in succession by J-P Revel, DE Johnson, CE Lyman, RL Price, and JF Mansfield, have made Microscopy and Microanalysis a leading international journal.

In 2002, the Society acquired Microscopy Today from Don Grimes who had self-published it since 1992. Ron Anderson was appointed Editor to continue self-publishing this magazine on behalf of MSA. Ron and his editorial team strengthened the magazine's standing among readers and advertisers. My time as Editor began in 2009.

The MSA book series, under the leadership of MS Isaacson and P Calarco, has two volumes in print: Scanning Electron Microscopy for the Life Sciences (H Schatten) and Liquid Cell Electron Microscopy (FM Ross). Several other volumes are nearing completion.

Thus, MSA's publications portfolio has been building for 50 years. Communications with microscopists continually expand through digital editions of publications and interactions via social media: Twitter, LinkedIn, Facebook, and Instagram. The Microscopy Society of America and our publisher, Cambridge University Press, have plans to expand our digital opportunities as we continue our tradition as a premier source for microscopy information.

Charles Lyman

Editor-in-Chief

Publication Objective: to provide information of interest to microscopists.

Microscopy Today is a controlled-circulation trade magazine owned by the Microscopy Society of America that is published six times a year in the odd months. Editorial coverage spans all microscopy techniques including light microscopy, scanning probe microscopy, electron microscopy, ion-beam techniques, and the wide range of microanalytical methods. Readers and authors come from both the life sciences and the physical sciences. The typical length of an article is about 2,000 words plus figures and tables; feature articles are longer. Interested authors should consult "Instructions for Contributors" on the Microscopy Today website: www.microscopy-today.com.

\section{ISSN 1551-9295}

\section{Disclaimer}

The Microscopy Society of America and the editors cannot be held responsible for opinions, errors, or for any consequences arising from the use of information contained in Microscopy Today. The appearance of advertising in Microscopy Today does not constitute an endorsement or approval by the Microscopy Society of America of any claims or information found in the advertisements. By submitting a manuscript to Microscopy Today, the author warrants that the article is original or that the author has written permission to use copyrighted material published elsewhere. While the contents of this magazine are believed to be accurate at press time, neither the Microscopy Society of America, the editors, nor the authors can accept legal responsibility for errors or omissions.

\section{Editorial Staff}

Charles E. Lyman, Editor-in-Chief charles.lyman@lehigh.edu (610) 758-4249

Gennifer Levey, Production Manager glevey@meridianartpro.com

(212) 780-0315

Ron Anderson, Executive Editor randerson20@tampabay.rr.com

Phil Oshel, Technical Editor oshellpe@cmich.edu

Robert Price, Associate Editor

bob.price@uscmed.sc.edu

Stephen Carmichael, Columnist

carmichael.stephen@mayo.edu

Eric Clark, Pioneers Editor

eclark@magnet.fsu.edu

Steven Barlow, Education Editor

sbarlow@mail.sdsu.edu

Deb Kelly, Microscopy 101 Editor

debkelly@vt.edu

Thomas E. Phillips, Consulting Editor

phillipst@missouri.edu

Paul Webster, Calendar Editor

pwebster@usc.edu

John Shields, Humor Editor

jpshield@uga.edu

Nikolaus Cordes, Digital Content Editor ncordes@lanl.gov

Thomas Kelly, Chief Awards Judge

Thomas.kelly@ametek.com

Advertising Sales

M.J. Mrvica Associates, Inc.

2 West Taunton Avenue, Berlin, NJ 08009 mjmrvica@mrvica.com

(856) 768-9360

Kelly Miller, Account Manager

kmiller@mrvica.com

Magazine website:

http://www.microscopy-today.com

Free subscriptions are available

Publisher

Cambridge University Press

One Liberty Plaza, 20th Floor

New York, New York 10006

(212) 337-5000

Circulation: 18,000

Editorial Board

Arlan Benscoter, Lehigh University

John Bozzola, Southern Illinois University

Peter Crozier, Arizona State University

Vinayak Dravid, Northwestern University

David Grubb, Cornell University

Bryan Huey, University of Connecticut

Heather Lowers, U.S. Geological Survey

John Mackenzie, North Carolina State Univ.

Paul Maddox, U. of North Carolina-Chapel Hill

Ania Majewska, U. Rochester Med School

Joseph Michael, Sandia National Labs

Caroline Miller, Indiana University

Brian M. Patterson, Los Alamos National Lab

John Reffner, John Jay College, SUNY

Ian Robertson, University of Wisconsin

Phillip Russell, Appalachian State University

Glenn Shipley, Citizen Microscopist

Robert Simmons, Georgia State University

Bradley Thiel, SUNY Polytechnic Institute

Paul Voyles, University of Wisconsin

Simon Watkins, University of Pittsburgh

Cynthia Zeissler, Nat. Inst. of Stds. and Tech. (NIST) 